\title{
On the Logic of Fiscal Policy Coordination in a Monetary Union
}

\author{
Oliver Landmann \\ University of Freiburg
}

revised, July 2017

\begin{abstract}
Fiscal policies have been widely criticized for their failure to act as a stabilizing countercyclical force in the European Monetary Union (EMU) prior to the Financial Crisis of 2008, and even more so thereafter. Motivated by EMU experience, this paper lays out a parsimonious model of fiscal-monetary policy interaction between national fiscal authorities and a common central bank. It is well known that the structure of this interaction changes fundamentally when the central bank is constrained by a binding zero lower bound on the interest rate. The key result of this paper is that decentralized fiscal policies suffer from a systematic procyclical bias in a monetary union, both when the zero lower bound bites and when it does not. Whereas the existing literature on fiscal policy coordination knows "locomotive games" and "discipline games", in which fiscal policies are too tight or too loose, respectively, the analysis in this paper identifies a "stabilization game" in which coordination can play a useful role by strengthening the countercyclical thrust of fiscal policies.
\end{abstract}

JEL Classification: E5, E6, F41, F42

Keywords: Fiscal Policy, Monetary Union, Multiplier, Spillovers, International Policy Coordination

\section{Acknowledgements}

A previous version of this paper was circulated as "EMU and the Cyclical Behavior of Fiscal Policy: A Suggested Interpretation" (University of Freiburg, Department of International Economic Policy, Discussion Paper Series, Nr. 29, ISSN 1866-4113). It was written while the author was a visiting research professor at the Economic Research Center of the Graduate School of Economics, Nagoya University, whose hospitality is gratefully acknowledged. The author thanks three anonymous referees as well as seminar participants at the Economic Research Center, Nagoya University, at the Research Institute for Economics and Business Administration, Kobe University, and members of the standing field committee for macroeconomics of the Verein für Socialpolitik (German Economic Association) for valuable comments. Rafael Mentges and Ksenia Khlopushina provided excellent editorial assistance.

Universität Freiburg

Institut für Allgemeine Wirtschaftsforschung

Platz der Alten Synagoge

D-79085 Freiburg

Germany

phone ++49 761-203-2326

e-mail: oliver.landmann@vwl.uni-freiburg.de

http://www.macro.uni-freiburg.de/news/home 


\section{Introduction}

The fiscal policy framework of the European Monetary Union (EMU), laid down in the Treaty of Maastricht and in the Stability and Growth Pact, is predominantly designed to prevent excessive borrowing by EMU member governments. The role of fiscal policy as a device for countercyclical macroeconomic stabilization, if not completely neglected, is subordinated to public debt stabilization. The European Central Bank (ECB) was put in place as the sole guardian of macroeconomic stability - its mandate being confined to preserving price stability. The standard arsenal of monetary policy allows the ECB to target monetary conditions in the Union as a whole, but not the macroeconomic state of individual member countries. This gap in the EMU's macroeconomic policy framework has been widely criticized early on (EEAG 2003).

As it turned out, the EMU experienced more macroeconomic turmoil than the ECB could handle alone. The ECB was neither equipped to deal with the asymmetric forces that led to a distinct divergence of macroeconomic conditions across the eurozone upon the creation of the EMU in 1999 (Landmann 2011, 2012, Nechio 2011) nor did it have a strong hand fighting the Great Recession of 2009 after interest rates had fallen to near the lower zero bound. Both episodes breathed new life into the debate on the proper role of fiscal policy in safeguarding the macroeconomic stability of the eurozone and, in view of the absence of a fiscal union, also raised questions with regard to the institutional framework for any such fiscal action, including the issue of policy coordination (Wren-Lewis 2013, Calmfors and WrenLewis 2011).

Fiscal-policy coordination was the subject of a sizable literature in the early years of the EMU. See Beetsma and Giuliodori (2010) for a survey. Much of this work was in the tradition of an older literature on the international coordination of monetary policies, investigating the role of discretion versus commitment in the face of disturbances to a short-run trade-off between unemployment and inflation (Neck/Dockner 1995). In this context, different types of strategic interaction and the role of conflicting objective functions among policy authorities were analyzed (Beetsma et al. 2001; Dixit/Lambertini 2001 and 2003; Kempf/von Thadden 2013). 
However, as events unfolded, the major challenges to macroeconomic stability in the EMU did not revolve around the inflation-unemployment trade-off. The first major challenge to the macroeconomic management of the EMU was the rapid elimination of eurozone interest-rate spreads due to the elimination of currency risk. Former high-interest-rate countries now had access to a large pool of cheap capital, which acted as a strong stimulus to their domestic demand and thus as an asymmetric shock to EMU as a whole (Baldwin/Giavazzi 2015). Later, once the boom had ended, fiscal authorities across the eurozone, having piled up large amounts of government debt in dealing with the financial crisis of 2008 and the Great Recession of 2009, turned to austerity, which acted as a major impediment to recovery (Corsetti 2012).

The behavior of fiscal authorities in the course of these events has motivated the design of the analytical structure proposed in the present paper. The argument is built around an intentionally parsimonious model designed to capture the relevant aspects of fiscal-monetary policy interaction in a monetary union and to study the scope for fiscal-policy coordination. The analysis goes beyond earlier contributions to the international fiscal-policy coordination literature in three major ways: First, the paper explores the scope for fiscal-policy coordination in the face of an asymmetric shock originating in the financial markets as experienced by the eurozone in the early 2000s. ${ }^{1}$ Second, it highlights how the scope and logic of fiscalpolicy cooperation is transformed when the central bank's interest-rate policy gets constrained by the zero lower bound. Third, the paper goes beyond the coordination games that have typically been studied in the existing literature. In his recent authoritative survey of the fiscal-policy coordination literature, Frankel (2016) distinguishes models of "locomotive games" and models of "discipline games" in which non-cooperative policy is too tight or too loose, respectively. The analysis below, in contrast, identifies a "stabilization game" in which fiscal policies suffer from a systematic procyclical bias. Whether or not monetary policy has traction: In either case, policy coordination can play a useful role by strengthening the countercyclical thrust of fiscal policies.

The remainder of the paper is structured as follows. The next section briefly reviews the basic facts about the cyclical behavior of eurozone fiscal policies that motivate the subse-

\footnotetext{
1 The role of cooperation versus non-cooperation in response to financial market shocks has generally remained underexplored in the open economy macro literature to date (Engel 2015).
} 
quent analysis. Section 3 employs a symmetrical two-country format to illustrate both the multiplier and the cross-border spillover effects of fiscal policies in a monetary union, highlighting the sensitivity of these effects to the prevailing monetary-policy regime. Based on this analysis, the paper proceeds to study the scope for fiscal policy coordination in alternative settings. In doing so, the analysis employs a government objective function first proposed by Uhlig (2003), but it goes beyond that paper by taking account of direct demand spillovers between countries. Section 4 considers the scope for fiscal-policy coordination when the monetary union is hit by an asymmetric shock. Section 5 turns to the scenario of an "austerity shock", i.e. a shift of fiscal policy priorities towards austerity while the central bank is constrained by the ZLB. Section 5 concludes.

\section{Fiscal policies and macroeconomic stability in the eurozone: some facts}

For any study of fiscal policy in the eurozone, it is useful to distinguish the two time periods before and after the watershed of the Global Financial Crisis and the Great Recession of 2008/09. In the first period, after the launch of the common currency, the euro area was exposed to strong centrifugal forces that led to massive macroeconomic disequilibria between member countries. Strong growth of domestic demand, fuelled by a credit bubble, propelled a number of mainly peripheral countries into an inflationary boom. At the same time, the core of the EMU, in particular Germany, suffered from an extended period of stagnation and high unemployment. As a consequence, the one-size-fits-all monetary policy of the ECB, while reasonably successful in maintaining macroeconomic stability for the eurozone as a whole, did not fit the differing needs of individual members at all (Nechio 2011).

In this situation, did national fiscal policies step in as a stabilizing force, addressing the divergent macroeconomic conditions in the core and the periphery? The empirical literature on this period has not found strong evidence for a systematically countercyclical stance of fiscal policies (Huart 2013, Bénétrix/Lane 2013). Fatas and Mihov (2009) even find a "mildly procyclical" pattern of fiscal policies which was not significantly altered by the introduction of the common currency. Many see the failure of the governments of booming eurozone countries to contain their booms by tighter fiscal policies as a "missed opportunity" (Lane 2012). 
The two panels of Figure 1, using OECD data, plot the cyclical positions of euro area member states against their fiscal policy behavior during the pre-financial-crisis period from 2003 to 2007, and in the aftermath of the Great Recession, 2009-2014, respectively. Cyclical conditions are measured by the average output gap for the period. Fiscal impulses are measured by the change in primary structural government balances. As the upper panel of Figure 1 shows, all eurozone countries, except Germany, experienced a period of above-normal economic activity (positive average output gaps) during 2003-2007. While some countries increased their primary structural balances during this period, others allowed fiscal policy to heat up their booming economies even further, Greece and Ireland being the worst offenders. To contain macroeconomic divergence in the eurozone, countries with higher than average output gaps would have had to run a fiscal policy tighter than the average and vice versa for countries with lower than average output gaps. In actual fact, however, the upper panel of Figure 1 displays the opposite pattern of behavior. Thus, fiscal policies exacerbated the divergence of private-sector spending patterns.

When the bubble in the periphery burst and domestic demand collapsed in 2008/09, boom turned into recession. The countercyclical response of macroeconomic policies to this downturn was short-lived: Monetary policy was soon constrained by interest rates approaching the zero lower bound (ZLB) and fiscal policy, in the face of a mountain of debt resulting from stimulus programs and bank bail-outs, had sharply turned towards austerity by 2010 . The lower panel of Figure 1 shows all eurozone economies tightening their fiscal policy stance while suffering from substantial slack (negative output gaps). Moreover, across countries, the pro-cyclicality of policies correlates positively with the severity of the output contraction.

Empirical studies of this period have found a substantial recession-deepening effect of fiscal austerity in the eurozone (Holland 2012, In't Veld 2013). As Obstfeld (2013, p. 48) has summarized the evidence, "the ex post imposition of austerity after a financial and debt crisis is underway, and especially when several neighboring countries are acting similarly, can have devastating output effects." Analytically, this diagnosis raises questions about the role of interaction effects for the macroeconomic impact of such simultaneous fiscal tightening and also about the potential scope for international coordination in dampening the impact. These are the questions that are addressed below. 
Figure 1: Cyclical conditions and fiscal impulses in the euro area, 2003-07 and 2009-14

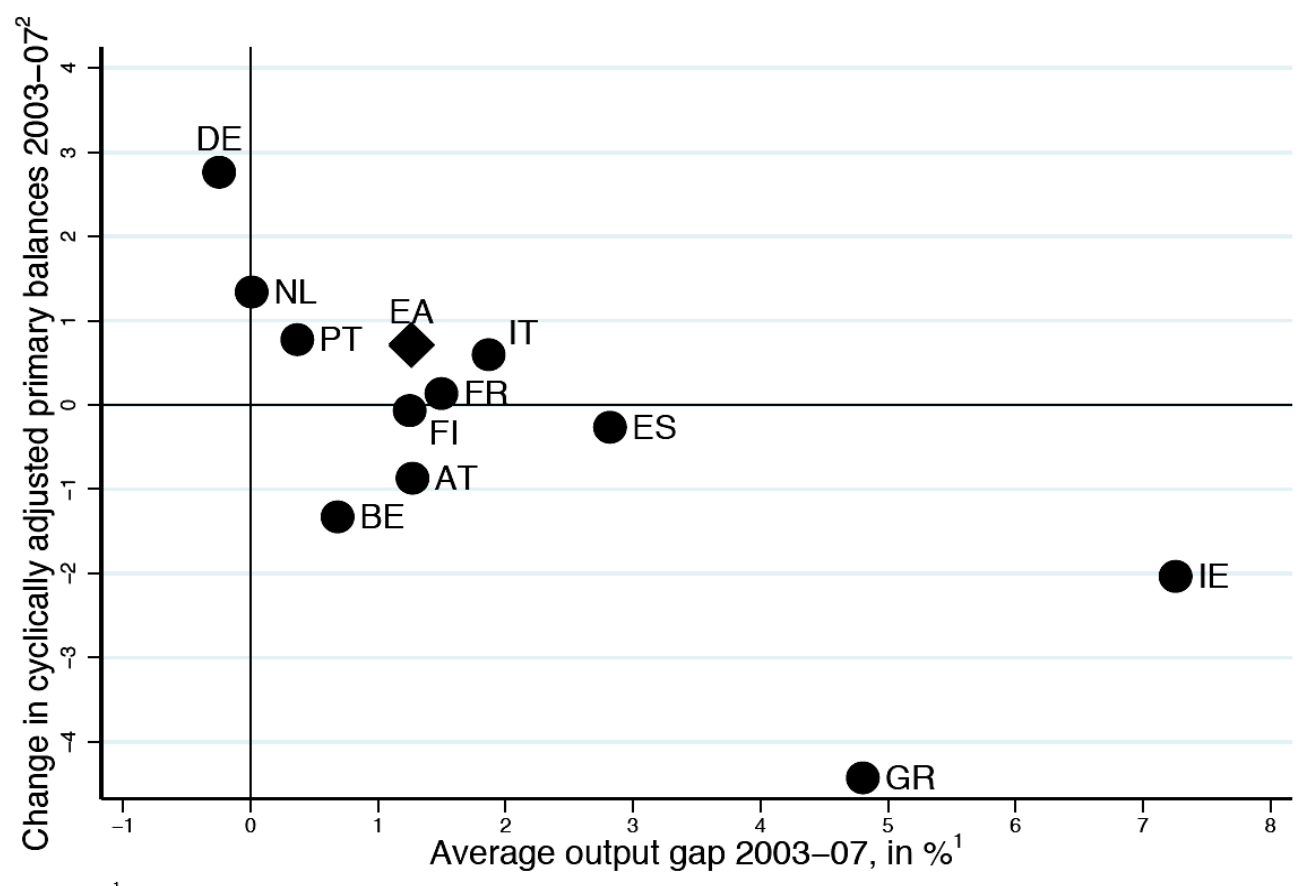

1 Source: Economic Outlook 97 database, 2015

(a) 2015

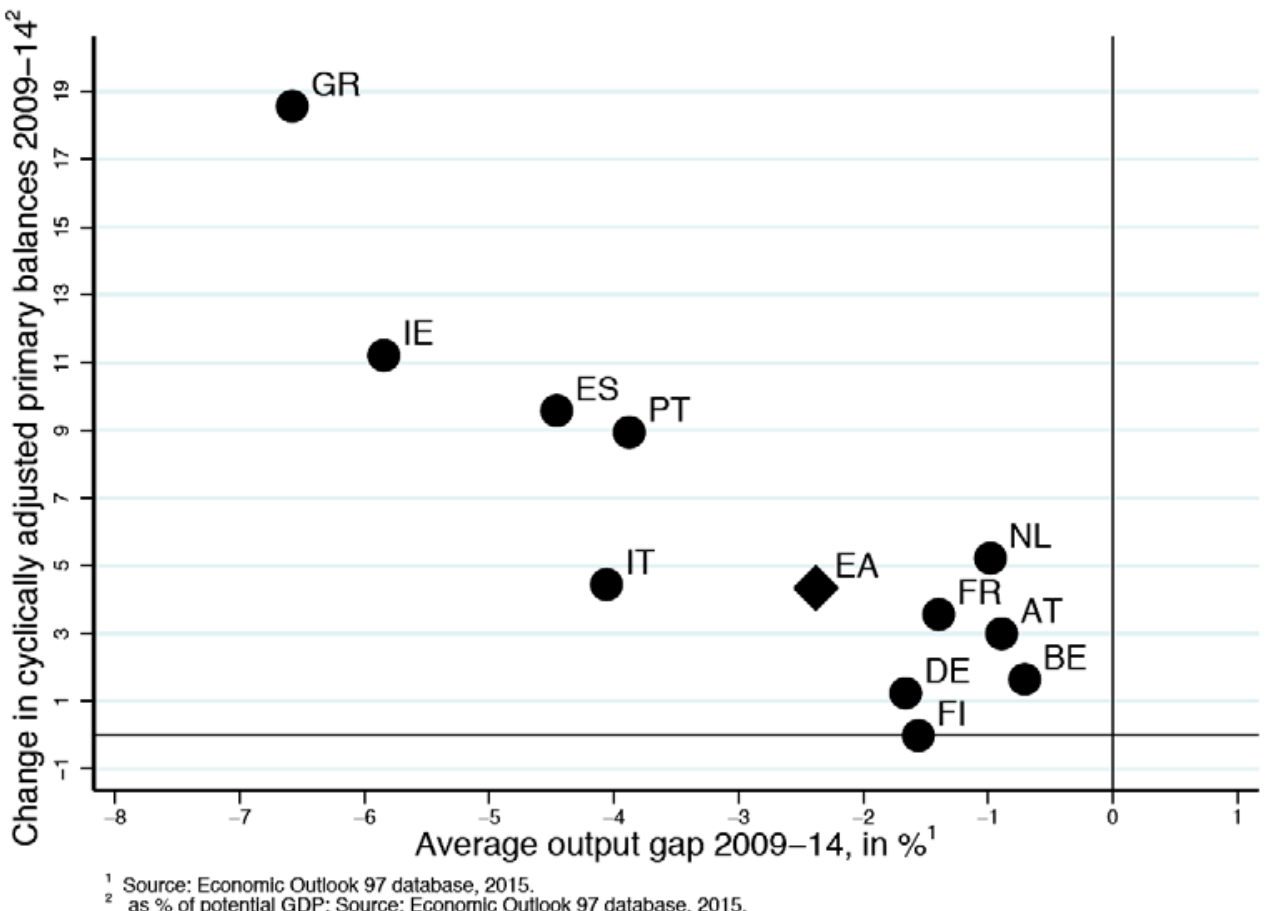

as $\%$ of potentlal GDP; Source: Economic Outlook 97 database, 2015. 


\section{Fiscal and monetary policy interaction in a monetary union}

In a monetary union that is not also a fiscal union at the same time, monetary policy interacts with many national fiscal policies and the latter interact with each other. A lot of attention has recently been devoted to the theoretical and empirical analysis of fiscal policy and its interaction with monetary policy. In New-Keynesian DSGE models, a multitude of factors - demand-side and supply-side, actual and expectational - determine the effects of fiscalpolicy actions. It seems fair to say that a broad consensus has emerged on the following propositions:

1. At the level of any given country or currency area, the scope and the need for countercyclical fiscal stabilization is negligible as long as monetary policy has traction.

2. Fiscal policy can become a rather powerful stabilizing tool, however, when monetary policy cannot react to macroeconomic disturbances, in particular when it is constrained by a binding ZLB (Woodford 2011, Eggertson 2014, Christiano et al. 2011).

3. National fiscal policies have a country-specific stabilization role in a currency union where monetary policy is in charge of monetary stability for the union as a whole (Galí and Monacelli 2008, Illing and Watzka 2014).

4. If the central bank of a monetary union has traction and uses its policy interest rate to maintain macroeconomic stability for the union as a whole, an increase in government spending in one country, while being expansionary at home, reduces the demand for output in the rest of the union (Farhi and Werning 2012, Hollmayr 2013).

5. If the policy rate of a monetary union is up against the ZLB, however, the spillover effect of national fiscal policy on demand in the rest of the union is strong and positive (Farhi and Werning 2012, Holland 2012, In't Veld 2013, Blanchard et al. 2016).

To fix ideas, and to facilitate the subsequent analysis of fiscal-policy coordination, the remainder of this section lays out a formal structure of fiscal-monetary policy interaction in a monetary union. It is cast in a symmetrical, static two-country format, stripped of the bells and whistles of current New-Keynesian modeling, but fully taking into account direct demand spillovers between the members of the union. The model is simple enough to permit a largely non-technical exposition, and yet capable of capturing the key propositions listed 
above. As a first step, equilibrium conditions are specified for the interconnected goods markets of the two countries, denoted by $N$ (North) and $S$ (South):

$y_{i}=-\delta_{0} r_{i}+\delta_{1}\left(p_{j}-p_{i}\right)+\delta_{2} y_{j}+\delta_{3} g_{i}, \quad i, j=N, S ; i \neq j ; \quad \delta_{0}, \delta_{1}, \delta_{3}>0 ; \delta_{2} \in[0,1]$

y: output, measured as deviation from potential output (output gap); r: real interest rate; p: log of price level; $g$ : fiscal policy variable (increase in $g=$ stimulus).

The two equilibrium conditions in equation (1) relate the demand for output in each country to the real interest rate, the relative price level (a measure of intra-union competitiveness), economic activity in the other country (foreign trade multiplier), and to fiscal policy, where $g$ is best thought of as a fiscal impulse measure such as the cyclically adjusted deficit (relative to potential output). For simplicity, the currency union is treated as a closed economy. In an open-economy setting, global economic variables and the external exchange rate of the union vis-à-vis the rest of the world would make an appearance as well. However, none of the five propositions stated above depends on this generalization in any significant way so that nothing is lost by retaining the simpler closed-economy format for the aggregate currency union. $^{2}$

National interest rates may differ by a spread $\rho$ which is treated as exogenous in this paper: ${ }^{3}$

$r_{S}=r_{N}+\rho$

In a long-run equilibrium, defined by flexible price levels and zero output gaps, the three equations (1) and (2) determine the two real interest rates and the intra-union real exchange rate while the absolute price level of the union remains to be determined by monetary poli-

\footnotetext{
2 A major consequence of modelling the currency union as an open economy would concern the transmission of changes in the level of interest rates to the goods market. In addition to the transmission channel running via domestic demand, expressed by $\delta_{0} \cdot r$ in equation (1), there would be a second channel via the external exchange rate and net exports into the rest of the world. It is straightforward to show that none of the results derived below would change if the currency union were modelled as an open economy.

3 There is a substantial literature on the causes of the variation in interest-rate spreads. The analysis in section 3 below applies to asymmetric shocks of any type, whatever their origin.
} 
cy. In the short run, nominal prices are assumed to be fixed so that exogenous demand shocks are fully reflected by changes in output. In a more general setting, a Phillips curve or an aggregate supply function would generate a joint short-run response of output and prices. Such a generalization would be indispensable for any explicit consideration of mediumterm dynamics or for an analysis of supply shocks. However, the focus below is on the shortrun shock absorption in the case of demand-side disturbances which call for a demand-side response regardless of the shape of the aggregate supply relation.

Figure 2 demonstrates how the model works in the short run, with $y_{S}=f\left(y_{N}, \ldots\right)$ and $y_{N}=f\left(y_{S}, \ldots\right)$ representing the symmetrical output equations (1) for given fiscal policies, price levels and interest rates. An initial long-run equilibrium of the monetary union is assumed to be located in point $A$ where both output gaps are zero. The slopes of the two schedules express the direct demand spillovers between the two countries. In addition, indirect spillovers can arise through the conduct of monetary policy by the central bank. The latter can control the real interest rate in the short run due to the nominal rigidity of the price level. ${ }^{4}$

As a purely illustrative example, Figure 2 describes an exogenous demand contraction in one of the two countries, North $\left(d g_{N}<0\right)$. This asymmetric shock shifts the $f\left(y_{S}, \ldots\right)$ schedule downwards by the amount $\delta_{3} d g_{N}$ (distance $\mathbf{A B}$ ). If the central bank is concerned about the macroeconomic stability of the aggregate monetary union and has been on target in point $\mathbf{A}$, it will not allow this exogenous shock to reduce the aggregate output gap (the mean of $y_{N}$ and $\left.y_{S}\right)$. Rather, the central bank will neutralize the effect of the demand shock on the aggregate output gap by following an interest-rate rule which can be derived from a framework of optimizing monetary policy, as shown in the Appendix (eq. A7). ${ }^{5}$ In terms of Figure 2, monetary policy forces the system onto the downward sloping $45^{\circ}$ line through point $\mathbf{A}$ which expresses the condition of a zero aggregate output gap $\left(y_{N}=-y_{S}\right)$. The easing of

4 Literally speaking, it is the nominal rather than the real interest rate which is under the direct control of the central bank. But in any environment of less than perfect price flexibility, the central bank sets the nominal interest rate with a view to its intended level of the real rate since it is the latter which is relevant for the transmission of monetary policy to the real economy. Treating the real rate as the lever used by the central bank is shorthand for this type of interest-rate policy.

${ }^{5}$ The prediction that the central bank immediately neutralizes demand shocks disregards lags in the monetary transmission process, but is quite common in New Keynesian models of monetary policy - a result which can also be rationalized in a more explicitly dynamic framework such as the one in Clarida et al. (1999). 
monetary policy shifts $y_{N}=f\left(y_{S}, \ldots\right)$ upwards and $y_{S}=f\left(y_{N}, \ldots\right)$ to the right until they intersect on the downward sloping $45^{\circ}$ line at a point such as $\boldsymbol{C}$.

Figure 2: Effect of a demand shock, conditional on the monetary-policy environment

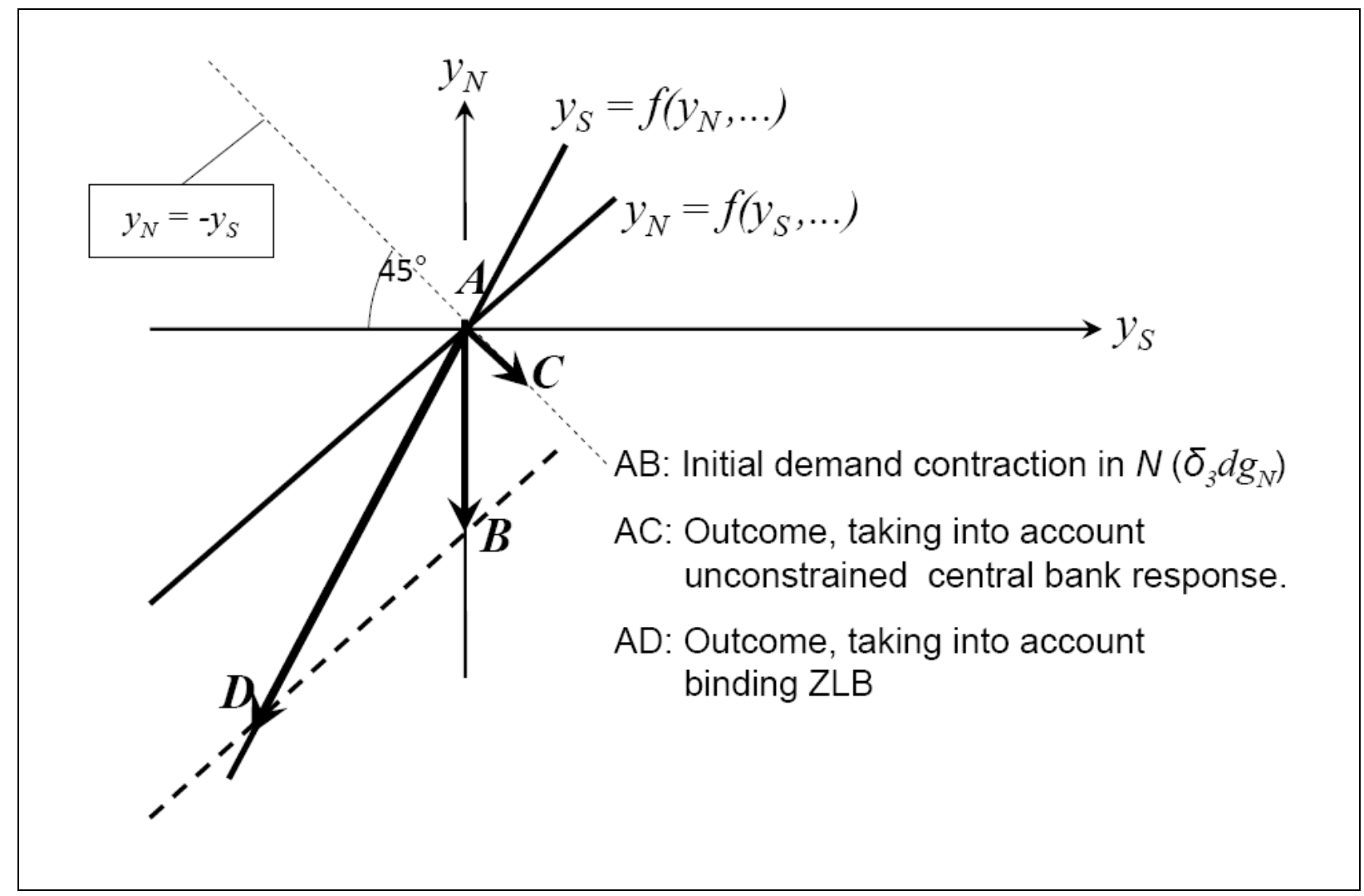

Clearly, the response by the central bank reduces, but does not eliminate, the multiplier effect of $d g_{N}$ on $y_{N}$. At the same time, the interest-rate cut causes $y_{S}$ to rise. Thus, the induced response of the central bank overrides the contractionary direct spillover effect of the initial shock and creates an inverse transmission of the shock between the two countries. ${ }^{6}$ Generally speaking, the assumed monetary-policy regime turns any demand shock that is not completely symmetrical among countries into a pure asymmetric shock which drives output in the two countries into opposite directions by the same amount. A formal derivation of this result is given in Appendix 1.

\footnotetext{
${ }^{6}$ In a monetary union that is open to the rest of the world, the inverse transmission is likely to involve the external exchange rate of the union, as pointed out above. Cwik/Wieland (2011) found this transmission channel at work in the euro area.
} 
A rather different picture emerges if monetary policy is constrained by the ZLB, which was largely the case for the ECB since 2009 after it had lowered the interest rate to near zero in response to the financial crisis. In this scenario, the effects of a demand shock are no longer conditioned by the induced interest-rate response of an optimizing central bank as before, but rather by an invariant zero interest rate. In Figure 2, the same unilateral demand shift $\mathbf{A B}$ that was translated into a movement $\mathbf{A C}$ before, now ends up taking the monetary union to point $\mathbf{D}$. Instead of being dampened by the central bank, the demand impulse is now amplified by the direct trade-induced spillovers between the countries so that output in South is dragged down as well. An obvious implication of this analysis is that fiscal-policy effects obtained from models calibrated to pre-crisis conditions cannot be used to assess fiscal policy under post-crisis conditions - a point that has been made forcefully by De Grauwe (2009). Formal expressions for the multiplier and spillover effects are provided in Appendix 1 for this case, too.

\section{An asymmetric shock when monetary policy has traction}

As pointed out in the introduction, there is broad agreement that a major factor behind the macroeconomic divergence during the first ten years of the European Monetary Union was the elimination of interest-rate spreads between the former "soft"-currency countries (roughly, the South) and the "hard"-currency countries (the North) - the prototype of an asymmetric shock. The model of the previous section can now be used to study the effects of and policy responses to such a shock. This is done here under the assumption that all policymakers - the two national governments and the common central bank - pursue their objectives independently, taking into account their exogenous environment, including the choices of the other decision-makers. In game-theoretic terms, they all play Nash. ${ }^{7}$ As explained above, the objective of the central bank is to neutralize any demand shock on the level of the aggregate monetary union. Fiscal authorities, in turn, are modeled along the

\footnotetext{
${ }^{7}$ The assumed Nash behavior may look more appealing if the two-country model is understood as the simple special case of a more general n-country structure. Alternative types of strategic interaction are explored in different set-ups by Beetsma et al. (2001), Dixit/Lambertini (2001), and Uhlig (2003). Letting fiscal authorities and the central bank move sequentially, as in Uhlig (2003), would not overturn the qualitative results obtained below.
} 
lines of Uhlig (2003), among others, who assumed that governments may face a trade-off between macroeconomic stability and fiscal targets such as debt or deficit targets. If $\bar{g}_{i}$ $(I=N, S)$ denotes the fiscal stance desired by governments when the macro-economy is in balance $\left(y_{i}=0\right)$, the preferences of the fiscal authorities can be expressed by

$$
L_{i}=\frac{1}{2}\left[y_{i}^{2}+\alpha\left(g_{i}-\bar{g}_{i}\right)^{2}\right] ; \quad i=N, S
$$

The quadratic loss function (3) punishes non-zero output gaps as well as deviations from the desired fiscal stance $\bar{g}_{i}$, with $\alpha$ expressing the relative importance of the fiscal target. Both governments minimize their loss functions (3), given the shocks and constraints they face. It follows immediately that in general it is not optimal for them to neutralize the output effects of country-specific shocks completely.

With this description of fiscal and monetary policy behavior in mind, the general-equilibrium repercussions of the assumed asymmetric shock can be traced out. The shock is modeled as a reduction of the intra-union interest-rate spread $\rho$ from some positive initial level to zero. The two governments and the central bank optimally set their instruments, each of them taking into account the instrument settings of the other policymakers and the state of the goods markets as expressed by equations (1) and (2). Under the continued assumption of short-run price rigidity, private-sector behavior and policy responses jointly determine the impact of the exogenous shock on the currency union and its individual members.

The outcome is best understood by thinking about monetary policy first. By eliminating the interest-rate differential between South and North, the exogenous shock relaxes monetary conditions in South relative to those in North. The central bank, in turn, has no reason to change its overall monetary stance for the aggregate union. Thus, it keeps the average interest rate of the union unchanged so that $r_{S}$ falls and $r_{N}$ rises by $\rho / 2$, respectively. In addition, the central bank stands ready to respond to changes in fiscal policies as explained above in Figure 2 (and as expressed by eq. A7 in Appendix 1).

Turning to fiscal policy, each government minimizes its loss function (3) by adjusting its fiscal instrument $g_{i}$ in response to changes in macroeconomic conditions. Those conditions de- 
pend on the interest-rate policy of the central bank, the fiscal actions of both governments and on the interest-rate spread $\rho$. This is how governments interact with the markets, with the central bank and, importantly, with each other. The resulting fiscal policies are expressed by the reaction functions $R_{N}$ and $R_{S}$ in Figure 3 . The reaction functions are the first-order conditions satisfied by each government solving its constrained optimization problem. A formal derivation is provided in Appendix 2.

In Figure 3, the reaction functions are drawn in terms of deviations of the respective fiscal instruments $g_{i}$ from their preferred levels $\bar{g}_{i}$. The positive slopes of $R_{N}$ and $R_{S}$ indicate that the two fiscal-policy instruments are strategic complements: When one government applies a fiscal stimulus, other things being equal, the other government will follow suit, though by less than one-for-one. This reaction pattern is a consequence of the inverse transmission of fiscal impulses explained above. Once the induced monetary-policy response is fully taken into account, a fiscal stimulus in one country reduces output in the other country, thereby giving the government of that country an incentive to apply some stimulus, too, in order to offset the recessionary spillover at least partially. The point of intersection of the two reaction functions (point $\mathrm{N}$ in Figure 3 ) is a Nash equilibrium as it is the only outcome in which the central bank and both governments are satisfied with their instrument settings, given the policy choices of the other players.

Figure 3 illustrates the policy responses to the elimination of a pre-existing interest-rate spread between South and North. Assuming a full initial (pre-shock) equilibrium in point $A$ with zero output gaps and zero deviations from desired fiscal policies in both countries ( $y_{i}=0, g_{i}=\bar{g}_{i}, i=N, S$ ), the downward adjustment of $\rho$ shifts the two fiscal-policy reaction functions to their positions shown in Figure 3. Not surprisingly, the asymmetric shock provokes opposite responses by the two governments: The reaction function $R_{S}$ shifts to the left from point $A$ as South is led to tighten its fiscal policy in order to counteract the stimulus entailed by its lower interest rate. By analogous reasoning, the $R_{N}$ function moves upwards as North eases its fiscal policy in response to the rise of its interest rate. The Nash equilibrium is in point $N$. Compared to the pre-shock equilibrium in point $A$, this outcome implies that both governments lean against the wind in a countercyclical way (tightening in South, easing in North). 


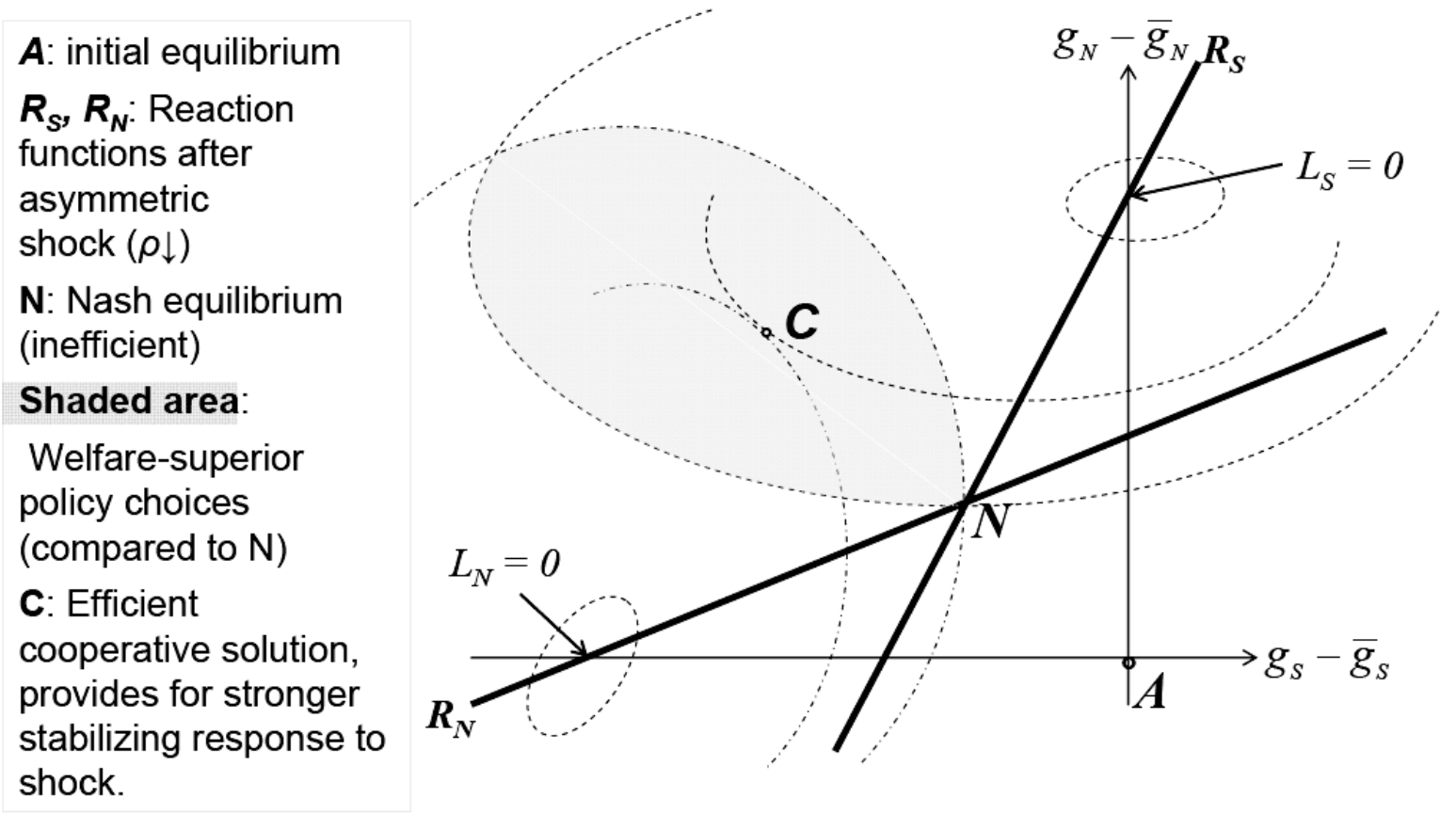

The thin, dotted indifference curves (iso-loss loci) indicate combinations of $g_{N}-\bar{g}_{N}$ and $g_{S}-\bar{g}_{S}$ that are regarded as equally desirable by the respective governments. Indifference curves in the vicinity of the "bliss points" - $\left(L_{N}=0\right)$ and $\left(L_{S}=0\right)$, respectively - are preferred to more distant indifference curves by each government. What the indifference curves reveal is that the Nash outcome (point $\mathrm{N}$ ) is inefficient. Both governments could improve their lot if they both acted in a more vigorously countercyclical manner, moving inside the shaded area. A benevolent social planner, minimizing a composite loss function of both governments, would choose a point such as $C$. The uncoordinated decentralized fiscal policy responses are obviously too weak.

The inefficiency of the Nash equilibrium results from the failure of each government to internalize the effects of its own actions on the other economy. In the presence of an asymmetric shock, and with the inverse cross-border transmission of fiscal impulses, any countercyclical fiscal reaction in one country has a stabilizing impact not only at home, but also abroad - a benign externality. The failure to internalize a benign externality leads to an undersupply of the activity generating it. This is an example of a strategic interaction in which international cooperation does not amount to suppressing undesired adverse externalities, 
as is so often the case in monetary-policy coordination models. Rather, desirable spillovers need to be strengthened in this case.

The analysis in Figure 3 also differs from standard models of international fiscal-policy coordination in that it fits neither a locomotive game, in which governments should agree on joint expansion, nor a discipline game, in which governments should agree on joint tightening (Frankel 2016). Rather, as governments trade off their fiscal objective against macroeconomic stability, they are engaged in a stabilization game in which their joint welfare is enhanced if they cooperate to move more forcefully in opposite directions, thereby reducing the size of costly output gaps in both countries.

The above analysis is not meant to provide a full explanation of fiscal policies observed in the eurozone in the years after the introduction of the euro. Rather, the model points to a source of the procyclical bias that is apparent from the failure of fiscal policies to counteract the divergence of private-sector demand growth in that period (as shown in Figure 1, above). Clearly, the analysis could be extended in several ways. For example, the elimination of interest-rate spreads has relaxed fiscal constraints in former high-interest countries as the cost of servicing existing government debt has come down. If this led governments to soften their fiscal targets, the procyclical bias of their fiscal policy was exacerbated.

Another extension would consider asymmetries in the structure of the model, such as differences in governments' preferences. $^{8}$ Suppose, for example, that North, faced with the rise in its domestic interest rate, did not wish to consider any major revision of its fiscal policy. In terms of the model, this case amounts to a scenario in which North attaches a higher weight $(\alpha)$ to its fiscal target in its objective function than does South. As a consequence, the elimination of the interest-rate spread is no longer neutral with regard to overall aggregate demand in the currency union. Compared to the baseline case described above, North relaxes its fiscal policy by less and South tightens by more so that the central bank is prompted to cut the overall interest rate in order to stabilize the aggregate economy of the monetary union. The Nash equilibrium in this case is still inefficient, but the benefits from policy coordination shrink if North values the spillover-induced output gains less highly.

\footnotetext{
8 The author thanks an anonymous referee for raising the question of how the results of the model would be affected by introducing asymmetry.
} 


\section{An austerity shock in a liquidity trap}

After starting a recovery from the Great Recession of 2009 for some two years, the eurozone fell back into renewed recession. At the same time, fiscal policy turned from stimulus to austerity. According to OECD (2015) data, the aggregate cyclically adjusted primary fiscal deficits of the eurozone, which had been increased by 3,3\% of GDP in $2008 / 09$, were slashed again by more than that amount subsequently. This sharp reversal of fiscal policy was all the more controversial at the time as the recession was far from over and the ECB had lowered its policy rate by enough to be constrained by the Zero Lower Bound for all practical purposes. Whereas De Grauwe and Ji (2013) denounced the simultaneous fiscal tightening across the eurozone as a panic-driven mistake, EEAG (2014) defended it as a bitter, though necessary medicine against fiscal profligacy.

Within the framework adopted above, the sudden turn of eurozone governments towards austerity can be represented as an "austerity shock", i.e. as an exogenous change of priorities within the objective functions. It is beyond the scope of this paper to model the economic motivations or external pressures that led to this shift. What the model can do, however, is to give a taste of the multiplier and spillover effects of the policy shift and to analyze the scope for international coordination as policies were recalibrated. Formally, the policy shift can be represented as a fall in $\bar{g}_{N}$ and $\bar{g}_{S}$ in the loss functions, not necessarily by the same amount. In contrast to the analysis in the preceding section, the central bank can no longer be assumed to stabilize aggregate union-wide output by adjusting the interest rate. Rather, the full consequences of the austerity shock must now be analyzed with reference to the fiscal multipliers and spillovers illustrated in Figure 2 above for the case of a liquidity trap.

Again, each government is assumed to set its fiscal policy so as to minimize its loss function (3), taking into account the determination of its output gap by the equations for the goods markets (1) and (2). However, the interaction of the two governments is now conditioned by an unmovable interest rate. As pointed out in section 3 above, this change in the monetary- 
policy environment reverses the sign of the cross-border transmission of a fiscal impulse. Not surprisingly, then, the shape of the fiscal-policy reaction functions changes as well.

The reaction functions now look as drawn in Figure 4, their negative slopes revealing the two fiscal-policy variables $g_{N}$ and $g_{s}$ as strategic substitutes: If one government cuts its deficit, it reduces demand abroad as well as at home, thereby creating an incentive for the government of the other country to apply some offsetting stimulus. Figure 4 also illustrates the general-equilibrium effects of an austerity shock, holding other exogenous variables constant, ${ }^{9}$ but taking into account all endogenous spillovers and reactions. Point $A$ again marks the starting point of the analysis - this time not necessarily a long-run steady state. The two axes plot $g_{N}$ and $g_{S}$, adjusted for their initial values $g_{N}^{A}$ and $g_{S}^{A}$, respectively. Of course, the austerity shock, which is assumed to hit both countries in the Figure, amounts to a fiscal tightening in both countries, as indicated by the displacement of the downward sloping reaction functions to their positions shown as $R_{N}^{Z L B}$ and $R_{S}^{Z L B}$, respectively.

Again, the short-run outcome is the Nash equilibrium at point $N$; and again, this equilibrium is inefficient. The point here is not to question the wisdom of governments preferring tighter fiscal policies in the first place. No matter whether the austerity is a panic-driven mistake or a necessary bitter pill, both governments apply excessive austerity even by the standard of their own revised preferences. They would both be better off if they simultaneously scaled down their policy adjustment, in which case they would end up in the shaded area of Figure 4. A benevolent social planner who shares the preferences of the fiscal authorities would minimize a composite loss function at a point such as $C$.

Why are the uncoordinated fiscal adjustments too strong in this case? Again, both governments fail to internalize the spillovers their own actions cause abroad. Since both policy shifts reduce demand abroad as well as at home in the presence of a liquidity trap, both governments export costly macroeconomic distress - a malign externality. With the underly-

\footnotetext{
${ }^{9}$ Instead of keeping all other things equal, one might wish in addition to trace the effects of a simultaneous return of interest-rate spreads. To keep the exposition transparent, the analysis of this extension is left to the reader.
} 
ing collective action problem remaining unresolved, the failure to internalize the malign externality induces an oversupply of the activity generating it.

Figure 4: An austerity shock when the ZLB is binding

A: initial equilibrium $R_{N}^{Z L B}, R_{S}^{Z L B}:$ Reaction functions after austerity shock

$\mathbf{N}$ : Nash equilibrium (inefficient)

\section{Shaded area:}

Welfare-superior policy choices (compared to $\mathrm{N}$ )

C: Efficient cooperative solution, provides for less aggressive austerity

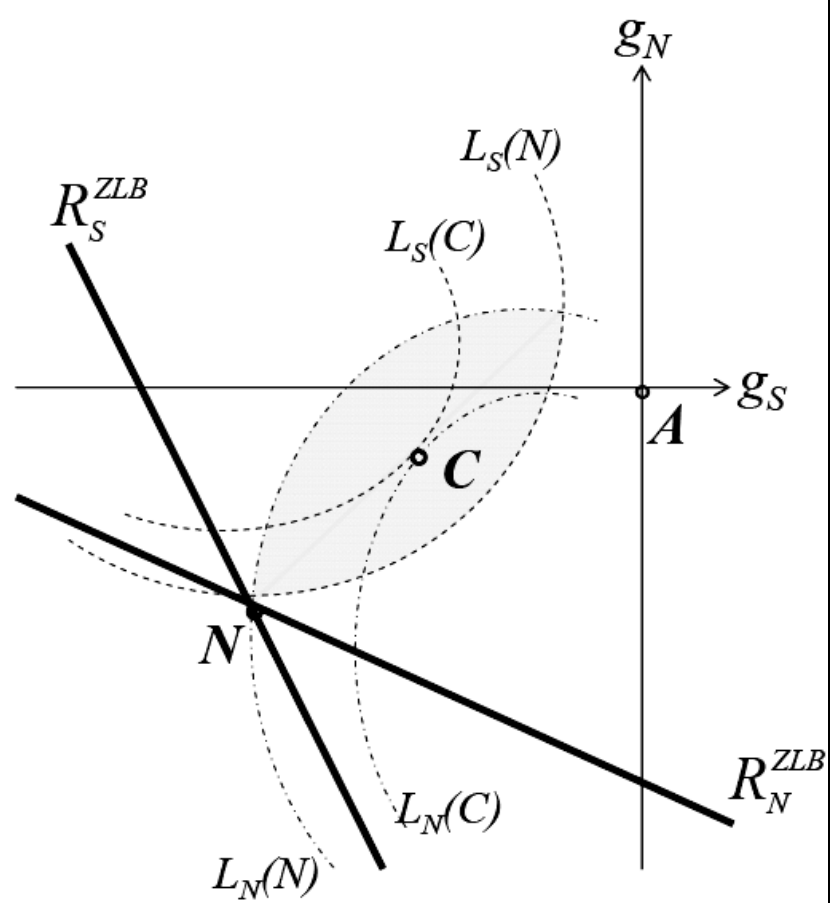

By highlighting the tension between fiscal discipline and fiscal stimulus, this example fits Frankel's (2016) "discipline game versus locomotive game" categorization of fiscal coordination games better than the scenario considered in the preceding section. However, the point made here differs from Frankel's concern that coordination may fail because governments cannot agree on the game they play. Rather, the message is that as governments are struggling to navigate between conflicting objectives, coordination could achieve a better outcome for all of them. In comparison to the case in which monetary policy has traction, fiscal multipliers and spillovers are larger under a binding ZLB constraint - and so are the gains from coordination.

Again, one might wish to explore the consequences of introducing some explicit asymmetry into the analysis. If, for example, the shift in fiscal preferences is less pronounced (or even absent) in North, how does the outcome in Figure 4 change? In this case, the downward shift 
of the northern reaction function from point $\boldsymbol{A}$ is evidently smaller than the one shown in Figure 4. As a consequence, the Nash equilibrium $\boldsymbol{N}$ is located further up on the reaction function of South, indicating less fiscal tightening by North, more fiscal tightening by South, and higher welfare (by the standard of government preferences) in South. The case for international cooperation is not overturned. Both governments would still be better off if they cooperated to relax their fiscal policies relative to the non-cooperative equilibrium $\boldsymbol{N}$.

\section{Conclusions}

This paper has employed a highly parsimonious model of optimizing fiscal authorities and of fiscal-monetary policy interaction to study the scope for international policy coordination in a monetary union. The analysis is motivated by the failure of fiscal policy to act as a stabilizing macroeconomic force in the European Monetary Union and it emphasizes the change in the nature of macroeconomic spillovers associated with the transformation of the monetary-policy environment when the interest rate hit the zero lower bound in the wake of the Global Financial Crisis of 2008. The model presented is not meant to provide a full explanation of these events or to capture the full dimension of the policy challenges they pose. Rather, it makes the narrower point that the failure of decentralized fiscal authorities to internalize cross-border spillovers entails a systematic procyclical bias for the policies they adopt. The fiscal coordination games described above are crucially shaped by the prevailing monetary-policy regime and thus allow for scenarios beyond the locomotive and discipline games that dominate the fiscal-policy coordination literature (Frankel 2016).

As all results of the international policy coordination literature, the conclusions reached in this paper are exposed to the objection that the identification of gains from international fiscal cooperation is a purely academic exercise, considering the powerful obstacles to the implementation of coordinated policies in a highly politicized domestic arena (Engel 2015). It appears indeed unlikely that the discretionary fiscal decisions of 19 EMU members could possibly overcome the incentive problems that would be associated with an international coordination of policies. However, insights from the analysis of coordination games can provide guidance for the design of fiscal institutions and rules that must be put in place to avoid the pitfalls of uncoordinated discretionary policy-making (Vogel et al. 2013). The fiscal archi- 
tecture of the EMU, in particular, is still in flux. Some advocate a hardening of existing rules; others set their hopes on the creation of a European Treasury or on the introduction of fiscal councils (Calmfors and Wren-Lewis 2011). Any functional institutional framework for fiscal policy in a monetary union is inevitably complex. ${ }^{10}$ In view of the dismal record of the fiscal framework enshrined in the Maastricht Treaty and in the Stability and Growth Pact, it may be tempting to argue that future fiscal institutions should be anchored and monitored on a strictly national level (Wren-Lewis 2013). In the light of the analysis in this paper, however, it is not advisable to bind sovereign countries into a monetary union without a reliable mechanism for coordinating the response of fiscal authorities to macroeconomic disturbances.

As stated at the outset, the analysis presented above proceeds with an absolute minimum of structure to clarify the logic of fiscal policy coordination in a monetary union. Obviously, such an exercise cannot do full justice to the complexities of fiscal policy and fiscal-monetary interaction in a monetary union. A more complete model would provide microfoundations to the behavioural equations and objective functions and it would explicitly take account of expectations and dynamics, including a model-based analysis of the conditions that give rise to the ZLB. A richer model would permit to address broader research questions such as the compatibility of long-term fiscal sustainability with short-term macroeconomic stabilization. Further research along these lines is desirable.

\section{References}

Baldwin, Richard, and Francesco Giavazzi (2015), 'The Eurozone Crisis - A Consensus View of the Causes and a Few Possible Remedies', A VoxEU.org eBook, CEPR Press London.

Beetsma, Roel, Xavier Debrun, and Franc Klaassen (2001), 'Is Fiscal Policy Coordination in EMU Desirable?', Swedish Economic Policy Review, Vol. 8, pp. 57-98.

Beetsma, Roel, and Massimo Giuliodori (2010), 'The Macroeconomic Costs and Benefits of the EMU and Other Monetary Unions: An Overview of Recent Research', Journal of Economic Literature, Vol. 48, pp. 603-641.

Bénétrix, Agustìn and Philip Lane (2013), 'Fiscal Cyclicality and EMU', Journal of International Money and Finance, Vol. 34, pp. 164-176.

\footnotetext{
${ }^{10}$ Portes and Wren-Lewis (2014) suggest some rules for dealing with this complexity.
} 
Blanchard, Olivier, Christopher Erceg, and Jesper Lindé (2016), 'Jump-Starting the Euro Area Recovery: Would a Rise in Core Fiscal Spending Help the Periphery?', forthcoming in NBER Macroeconomics Annual, 31, 2016.

Calmfors, Lars and Simon Wren-Lewis (2011), 'What Should Fiscal Councils Do?', Economic Policy, Vol. 26, pp. 649-695.

Christiano, Lawrence, Martin Eichenbaum, and Sergio Rebelo (2011), 'When Is The Government Spending Multiplier Large?', Journal of Political Economy, Vol. 119, pp. 78-121.

Clarida, Richard, Jordi Galí, and Mark Gertler (1999), 'The Science of Monetary Policy: A New Keynesian Perspective', Journal of Economic Literature, Vol. 37, pp. 1661-1707.

Corsetti, Giancarlo (2012), 'Has Austerity Gone Too Far?', VoxEu E-Book, available at www.voxeu.org/content/austerity-too-much-good-thing.

Cwik, Tobias und Volker Wieland (2011), 'Keynesian Government Spending Multipliers and Spillovers in the Euro Area', Economic Policy, Vol. 26, pp. 493-549.

De Grauwe, Paul (2009), 'To Coordinate or Not to Coordinate', VoxEu, 24. September, available at www.voxeu.org/article/coordinate-or-not-coordinate.

De Grauwe, Paul and Yuemei Ji (2013), 'Panic-driven austerity in the eurozone and its implications', VoxEu, 21. February, available at www.voxeu.org/article/article/panic-drivenausterity-eurozone-and-its-implications.

Dixit, Avinash and Luisa Lambertini (2001), 'Monetary-Fiscal Policy Interactions and Commitment versus Discretion in a Monetary Union', European Economic Review, Vol. 45, pp. 977-987.

Dixit, Avinash and Luisa Lambertini (2003), 'Symbiosis of Fiscal and Monetary Policies in a Monetary Union', Journal of International Economics, Vol. 60, pp. 235-247.

EEAG (2003), European Economic Advisory Group Report on the European Economy, Munich, Ch. 2, pp. 46-75.

EEAG (2014), European Economic Advisory Group Report on the European Economy, Munich, Ch. 3, pp. 75-90.

Eggertson, Gauti (2014), 'Fiscal Policy, Public Debt and the World Crisis', German Economic Review, Vol. 15, pp. 225-242.

Engel, Charles (2015), 'International Coordination of Central Bank Policy', NBER Working Paper No. 20952, February.

Farhi, Emmanuel, and Iván Werning (2016), 'Fiscal Multipliers: Liquidity Traps and Currency Unions', in Taylor, John and Harald Uhlig (eds.), Handbook of Macroeconomics, Vol. 2B, Chapter 31, 2417-2492. 
Fatas, Antonio und Ilian Mihov (2009), 'The Euro and Fiscal Policy', in Alesina, Alberto and Giavazzi, Francesco (eds.) Europe and the Euro (Chicago: Chicago University Press), pp. 287-324.

Frankel, Jeffrey (2016), 'International Coordination', in Glick, Reuven and Mark Spiegel (eds.), Policy Challenges in a Diverging Global Economy, Federal Reserve Bank of San Francisco, pp. 149-185.

Galí, Jordi and Tommaso Monacelli (2008), 'Optimal monetary and fiscal policy in a currency union', Journal of International Economics, Vol. 76, pp. 116-132.

Holland, Dawn (2012), 'Less Austerity, More Growth?', NIESR Discussion Paper, No. 400, London.

Hollmayr, Josef (2013), 'Fiscal Policy in the Euro Area Analyzed with a New-Keynesian MultiCountry Model', Discussion Paper, Deutsche Bundesbank, Frankfurt a.M.

Huart, Florence (2013), 'Is Fiscal Policy Procyclical in the Eurozone?', German Economic Review, Vol. 14, pp. 73-88.

Illing, Gerhard and Sebastian Watzka (2014), 'Fiscal Multipliers and Their Relevance in a Currency Union - A Survey', German Economic Review, Vol. 15, pp. 259-271.

In't Veld, Jan (2013), 'Fiscal Consolidations and Spillovers in the Euro Area Periphery and Core', European Economy, Economic Papers, No. 506, Brussels, October.

Kempf, Hubert and Leopold von Thadden (2013), 'When Do Cooperation and Commitment Matter in a Monetary Union?', Journal of International Economics; Vol. 91, pp. 252-262.

Landmann, Oliver (2011), 'On the Macroeconomics of European Divergence', CESifo Forum, Vol. 12, No. 2, pp. 19-25.

Landmann, Oliver (2012), 'Rotating Slumps in a Monetary Union', Open Economies Review, Vol. 23, No. 2, pp. 303-317.

Lane, Philip (2012), 'The European Sovereign Debt Crisis', Journal of Economic Perspectives, Vol. 26, pp. 49-68.

Nechio, Fernanda (2011), 'Monetary Policy When One Size Does Not Fit All', Federal Reserve Bank of San Francisco Economic Letter, No. 2011-18, June.

Neck, Reinhard and Engelbert Dockner (1995), 'Commitment and coordination in a dynamic game model of international economic policy-making', Open Economies Review, Vol. 6, No. 1, pp. 5-28.

Obstfeld, Maurice (2013), 'Finance at Center Stage: Some Lessons of the Euro Crisis', European Economy, Economic Papers, No. 493, Brussels, April.

OECD (2015), Economic Outlook, No. 97, Paris, May.

Portes, Jonathan and Simon Wren-Lewis (2014), 'Issues in the Design of Fiscal Policy Rules', Department of Economics Discussion Paper, No. 704, Oxford University, May. 
Uhlig, Harald (2003), 'One Money, but Many Fiscal Policies in Europe: What Are the Consequences?', In Mario Buti (ed.) Monetary and Fiscal Policies in EMU (Cambridge: Cambridge University Press), pp. 29-56.

Vogel, Lukas, Werner Roeger and Bernhard Herz (2013), 'The Performance of Simple Fiscal Policy Rules in Monetary Union', Open Economies Review, Vol. 24, No. 1, pp. 165-196.

Woodford, Michael (2011), 'Simple Analytics of the Government Expenditure Multiplier', American Economic Journal: Macroeconomics, Vol. 3, pp. 1-35.

Wren-Lewis, Simon (2013), 'Macroeconomic Stabilisation in the Eurozone: Lessons from Failure', Global Policy, Vol. 4, Suppl. 1, July, pp. 66-73. 


\section{Appendix 1: Derivation of Multipliers and Spillovers in Figure 2}

In section 3, the determination of multipliers and spillovers starts from the equilibrium conditions for the goods markets of the two symmetrical countries $N$ and $S$ as spelled out by equation (1) in the text. For the purpose of short-run analysis, price levels are held fixed and normalized at $p_{N}=p_{S}=0$ :

$y_{i}=-\delta_{0} r_{i}+\delta_{2} y_{j}+\delta_{3} g_{i}, \quad i, j=N, S ; i \neq j ; \quad \delta_{0}, \delta_{3}>0 ; 0<\delta_{2}<1$

y: output, measured as deviation from potential output (output gap);

r: real interest rate; $g$ : fiscal policy variable (increase in $g$ = stimulus);

The two national interest rates may differ by a risk premium $\rho$ :

$r_{S}=r_{N}+\rho$

It is useful to define the average interest rate of the currency union $r$ as

$r \equiv \frac{r_{N}+r_{S}}{2}$

The two equilibrium conditions (A1) are shown in Figure 2 as $y_{N}=f\left(y_{S}, \ldots\right)$ and $y_{S}=f\left(y_{N}, \ldots\right)$. Together with (A2) and (A3), they determine $y_{N}$ and $y_{s}$ as functions of $g_{N}, g_{s}, r$, and $\rho$ :

$\left[\begin{array}{c}y_{N} \\ y_{S}\end{array}\right]=\frac{1}{1-\delta_{2}^{2}} \cdot\left[\begin{array}{cccc}\delta_{3} & \delta_{2} \delta_{3} & -\delta_{0}\left(1+\delta_{2}\right) & \frac{\delta_{0}\left(1-\delta_{2}\right)}{2} \\ \delta_{2} \delta_{3} & \delta_{3} & -\delta_{0}\left(1+\delta_{2}\right) & \frac{-\delta_{0}\left(1-\delta_{2}\right)}{2}\end{array}\right] \cdot\left[\begin{array}{c}g_{N} \\ g_{S} \\ r \\ \rho\end{array}\right]$

The aggregate output gap of the currency union can be computed from (A4) as the average of $y_{N}$ and $y_{s}$ :

$\frac{y_{N}+y_{S}}{2}=\frac{1}{1-\delta_{2}} \cdot\left[\frac{\delta_{3}}{2}\left(g_{N}+g_{S}\right)-\delta_{0} r\right]$

The central bank controls the interest rate $r$ which it uses as its instrument in its pursuit of stability for the aggregate currency union. The standard representation of central bank preferences is an objective function with inflation and the output gap as arguments. Since the 
analysis in this paper does not address supply-side disturbances and the price level is assumed not to change in response to demand-side disturbances in the short run, the objective of monetary policy boils down to keeping the output gap of the aggregate currency union as close to zero as possible. Thus, the central bank sets the interest to minimize the quadratic loss function

$$
\Lambda=\left(\frac{y_{N}+y_{S}}{2}\right)^{2}
$$

Taking into account the determination of the aggregate output gap in (A5), it is straightforward to see that the minimization of $(A 6)$ yields a reaction function of the central bank in the form of the interest-rate rule

$r=\frac{\delta_{3}}{2 \delta_{0}} \cdot\left(g_{N}+g_{S}\right)$

For the sake of illustrating the role of the monetary policy regime for the determination of multipliers and spillovers, Figure 2 considers an asymmetric adverse demand shock in North $d g_{N}<0$ which shifts $y_{N}=f\left(y_{S}, \ldots\right)$ down by the distance $\mathbf{A B}$ at any given interest rate. If the central bank has traction, however, it adjusts the interest rate according to (A7). The multiplier effect $d y_{N} / d g_{N}$ and the spillover effect $d y_{S} / d g_{S}$ of the asymmetrical demand shock $d g_{N}<0$ can then be computed simply by substituting (A7) into (A4) and solving for

$\left[\left.\begin{array}{l}d y_{N} / d g_{N} \\ d y_{S} / d g_{N}\end{array}\right|_{[A 6]}=\frac{\delta_{3}}{2\left(1+\delta_{2}\right)} \cdot\left[\begin{array}{c}1 \\ -1\end{array}\right]\right.$

which is the movement AC in Figure 2. In contrast, if the central bank is constrained by the Zero Lower Bound (ZLB), it cannot adjust the interest rate $r$ to react to the shock. For given $r$ and $\rho$, then, the multiplier and spillover effects can be directly retrieved from (A4):

$\left[\left.\begin{array}{l}d y_{N} / d g_{N} \\ d y_{S} / d g_{N}\end{array}\right|_{r=\text { const. }}=\frac{\delta_{3}}{1-\delta_{2}^{2}} \cdot\left[\begin{array}{c}1 \\ \delta_{2}\end{array}\right]\right.$ 
which is the movement $A D$ in Figure 2. The multiplier expression in (A9) is more than twice as large as the corresponding multiplier in (A8) and the sign of the spillover, which was negative in (A8), is positive in (A9).

\section{Appendix 2: Derivation of the Reaction Functions in Figures 3 and 4}

In sections 4 and 5 , national governments are assumed to minimize

$$
L_{i}=\frac{1}{2}\left[y_{i}^{2}+\alpha\left(g_{i}-\bar{g}_{i}\right)^{2}\right] ; \quad i=N, S
$$

subject to the output gaps $y_{i}$ being determined by (A4). Taking account of (A4) in (A10), the two first-order conditions $\partial L_{i} / \partial g_{i}=0$ can be solved for $g_{i}(i=N, S)$ to yield

$$
\begin{aligned}
& g_{N}=\frac{1}{\delta_{3}^{2}+\alpha\left(1-\delta_{2}^{2}\right)^{2}} \cdot\left[-\delta_{2} \delta_{3}^{2} g_{S}+\delta_{0} \delta_{3}\left(1+\delta_{2}\right) r-\frac{\delta_{0} \delta_{3}}{2}\left(1-\delta_{2}\right) \rho+\alpha\left(1-\delta_{2}^{2}\right)^{2} \bar{g}_{N}\right] \\
& g_{S}=\frac{1}{\delta_{3}^{2}+\alpha\left(1-\delta_{2}^{2}\right)^{2}} \cdot\left[-\delta_{2} \delta_{3}^{2} g_{N}+\delta_{0} \delta_{3}\left(1+\delta_{2}\right) r+\frac{\delta_{0} \delta_{3}}{2}\left(1-\delta_{2}\right) \rho+\alpha\left(1-\delta_{2}^{2}\right)^{2} \bar{g}_{S}\right]
\end{aligned}
$$

As is evident from (A11), fiscal policymakers respond both to each other and to changes in the interest rate set by the central bank. However, if the central bank is caught in a liquidity trap as in the case of the austerity shock described in section 5, it cannot adjust the interest rate. Thus, (A11) directly provides the reaction functions shown as $R_{N}^{Z L B}$ and $R_{S}^{Z L B}$ in Figure 4 , thereby confirming that they must slope downward in $\left(g_{s}, g_{N}\right)$ space for any given $r$ and $\rho$. Also, not surprisingly, the austerity shock, i.e. the fall in $\bar{g}_{i}$, reduces $g_{i}$ so that both reaction functions shift down and to the left.

If the central bank has traction, however, as in the case of the shock to the interest-rate spread considered in section 4, the average interest rate $r$ is given by (A7). In this case, (A7) and (A11) together describe the behavior of the two governments and the central bank, each of them reacting to one another as well as to exogenous shocks. This trilateral interaction fundamentally alters the behavior of the two fiscal authorities. Formally, the fiscalpolicy reaction functions for this scenario are obtained by substituting (A7) into (A11): 


$$
\begin{aligned}
& g_{N}=\phi_{0} g_{S}+\left(1-\phi_{0}\right) \bar{g}_{N}-\phi_{1} \rho \\
& g_{S}=\phi_{0} g_{N}+\left(1-\phi_{0}\right) \bar{g}_{S}+\phi_{1} \rho \\
& \text { where }\left\{\begin{array}{l}
\phi_{0}=\delta_{3}^{2} \Delta^{-1} \in[0,1] \\
\phi_{1}=\delta_{0} \delta_{3} \Delta^{-1}>0 \\
\Delta=\delta_{3}^{2}+2 \alpha\left(1+\delta_{2}\right)^{2}\left(1-\delta_{2}\right)>0
\end{array}\right.
\end{aligned}
$$

Contrary to the case of the binding ZLB which gives rise to the downward sloping reaction functions in Figure 4, the reaction functions (A12) are both positively sloped in $\left(g_{s}, g_{N}\right)$ space, as shown by $R_{N}$ and $R_{S}$ in Figure 3. (A12) also confirms that any change in the interest-rate spread $\rho$ is a pure asymmetric shock, pushing $g_{N}$ and $g_{s}$ in opposite directions. 